\title{
Management Implications Of A Czech National Identity In The European Union
}

Heather L. Budden, University of New Orleans, USA

Connie B. Budden, Southeastern Louisiana University, USA

\begin{abstract}
The unique Czech identity played a role in the country's joining the European Union. There are a number of distinct characteristics of the Czech identity that are actually quite compatible to membership in the Union. The history of the Czech nation which has a significant impact on the national identity of the country is discussed along with an explanation or definition of national identity. The Czech identity and the European identity are compared and contrasted. Finally, management implications of the Czech identity are discussed.
\end{abstract}

\section{COUNTRY DESCRIPTION}

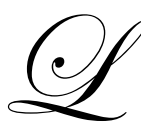

ocated southeast of Germany, the Czech Republic is a landlocked country in Central Europe. The Czech Republic is bordered by Germany, Austria, Poland, and Slovakia. The country has over ten million inhabitants boasting a 99 percent literacy rate. The Czech Republic is considered one of the more successful former Communist states of Central and Eastern Europe with an estimated GDP per capita of over $\$ 20,000$ dollars per year, slightly lower than the EU average. The country has a stable, parliamentary democracy. The capital is Prague and the country celebrates its national holiday, Czech Founding Day, on the $28^{\text {th }}$ of October; the holiday commemorates the founding of the Czechoslovak state (https://www.cia.gov/library/publications/theworld-factbook/index.html).

\section{EARLY HISTORY}

The historical lands of Moravia and Bohemia that are now the current location of the Czech Republic were settled by many tribes including Celts, German, and Slavs. The Great Moravian Empire, founded in 830 AD under Slavic leader Mojmir, collapsed after an invasion by Hungary in $907 \mathrm{AD}$ (http://www.myczechrepublic.com/czechhistory). Wenceslaus was the Duke of Bohemia between 921 AD and his death in $935 \mathrm{AD}$. According to legend he was killed by a brother that did not support his Christianity. For this reason he is considered a martyr, and is the patron saint of the Czech Republic (Johnson 2002).

Vratislav II became the first Czech king in $1085 \mathrm{AD}$ and ruled under the guidance of the Holy Roman Empire. The Premyslid Dynasty, which Vratislav II was a part of, ruled the area until 1306 AD. While the Premyslid Dynasty existed until 1306, by 1200 AD the Holy Roman Empire was already losing a great deal of its power and was a loose confederation of states (Johnson 2002).

The Hussites were the followers of Jan Hus who was a priest and reformer similar to Germany's Martin Luther; he was labeled a heretic by the Roman Catholic Church and subsequently burned at the stake in 1415. At this time some of the nobility in the region were Catholic while others were followers of Hus. Hus was considered to be very innovative and made many suggestions regarding reforming the Church. He is now celebrated as a martyr in the Czech Republic. The Hussite Wars broke out in 1419 after Sigismund of Luxembourg acceded to the Bohemian throne. Many people at the time believed Sigismund was responsible for the "murder" of Hus. According to Johnson (2002) Bohemian fighters showed a great deal of courage and ingenuity. Interestingly the Hussites ended divided with some actually siding with the Catholics against fundamentalists in their ranks; eventually leading to a civil war (Johnson 2002). 
The Habsburgs who gained control of the area in the 1500s ruled the Czech people until the first independent Czechoslovak state was formed in the year 1918. Roman Catholicism became the dominant religion in the area once again under the Habsburgs's rule. The Battle of White Mountain in 1620 which led to Prague losing prominence in the international community was a precursor to the Thirty Years War and part of the reason Roman Catholicism was declared the only legal religion. The battle was started by a failed Protestant uprising, and the Habsburgs won easily (Johnson 2002).

\section{NATIONAL REVIVAL}

Between the year 1790 and the First World War there was a movement in support of the use of the Czech language as well as widespread support to return to the national identity and culture of the Czech people. Czech literature became mainstream and its appreciation grew significantly. During the $1800 \mathrm{~s}$ a great deal of modernization and industrialization took place in the Czech nation. The assassination of Archduke Franz Ferdinand not only signified a decrease in power of the Habsburgs, but it is considered the key event that started World War I. The first independent state of Czechoslovakia was founded on October 28, 1918 with Prague as the capital city. This independent state lasted approximately twenty years when Germany invaded the country. Hitler invaded Czechoslovakia with the permission of France, Britain, and Italy. The countries agreed to this in the Munich Pact and by 1939 Czechoslovakia was under German occupation. The Germans would remain in control of the country until the end of the Second World War. The Soviets liberated Prague in 1945. At the same time, western regions of the country were liberated by United States forces (http://www.myczechrepublic.com/czech-history).

Between the years 1945 and 1989, Communists controlled the Czech Republic. During the time of the Communist regime, the vast majority of private companies were nationalized. Also, a number of human rights violations were reported. The 1960s were a time of reform in the Communist party of Czechoslovakia with Alexander Dubcek initiating a number of changes. Dubcek, the Communist Party Secretary, was determined to move away from some of the strict policies of Stalin. What is interesting and unusual about Czechoslovakia is that its own Communist Party was responsible for reforms as opposed to other Communist States where changes were often encouraged by outsiders (Johnson 2002).

During the spring of 1968, many reforms were initiated in Czechoslovakia and this era became known as the "Prague Spring." Many Czechoslovakians supported the changes implemented by the reformers. Dubcek enjoyed a great deal of popularity amongst the Czechoslovaks, and there was a feeling that Czechoslovakia was finally returning to Europe (Johnson 2002).

By August of the same year the Soviets had become suspicious of the reforms and invaded Czechoslovakia along with other member states of the Warsaw Pact. The Czechoslovakians did not fight back which makes a great deal of sense upon further examination of the Czech national identity. Czechs are often characterized as feeling as if they have no control over what happens to them; if the Czechs feel this way it would make sense for them to not attempt to struggle against the Soviets (Johnson 2002).

The same year the Berlin Wall fell, Czechoslovakia had its "Velvet Revolution" which precipitated the fall of Communism in that country. The "Velvet Revolution" consisted of student protests against the government that were subsequently dispersed by Czechoslovakian police. By the beginning of 1990, Czechoslovakia held its first democratic elections and Vaclav Havel was elected President.

While many Czechoslovakians were opposed to the idea, there was a growing movement to split the country into two independent states. The country was separated into a Czech nation and a Slovak nation in 1993; this separation was called the "Velvet Divorce." The process of separating the two countries was a peaceful one. The resulting states were the Czech Republic and Slovakia (http://www.myczechrepublic.com/czech-history).

The Czech Republic joined NATO in 1999. By 2004, the country was a Member State of the European Union (https://www.cia.gov/library/publications/the-world-factbook/index.html). 


\section{IDENTITY}

The word identity is defined in two separate ways. Identity can be defined as "the state or fact of remaining the same one or ones as under varying aspects or conditions" (http://dictionary.reference.com/browse/identity 2006). It can also be defined as "the condition of being itself or oneself and not another" (http://dictionary.reference.com/browse/identity 2006). As Jiri Brodsky mentions in "The Czech Experience of Identity," these two definitions are comparing people and things in two different manners. The first definition focuses on similarities while the second emphasizes differences (Brodsky 2001).

According to Brodsky (2001), national identity includes history, culture, geography, and the way the nation perceives itself; he believes that nations focus on the second definition of identity and emphasize what makes them different or unique in comparison to others. Brodsky goes on to say, "National identity is defined on the grounds of a nation's history and heritage and the prerequisite of a strong national identity is that citizens have a sense of loyalty, and of belonging to a particular nation" (Brodsky 2001 p. 21). As will be presented, the Czech Republic's national identity has been shaped by events that have happened in the past. In other words, the Czech Republic's history has had a significant influence on the country's national identity.

\section{CZECH IDENTITY}

Holy (1994) proffers that many see the separation of the Czech Republic and Slovakia as evidence of an increase in nationalism in the Czech identity; but he does not agree with this premise. While Holy acknowledges the existence of nationalism in Post-Communist states, he claims that extreme nationalism was not a contributing factor for the separation of Czechoslovakia. Holy (1994) argues that there had long been a form of political separation between the Czechs and Slovaks before the fall of Communism in 1989. That being said, Czech national identity is important to the Czech people. Much of the Czech identity has been influenced by the country's past.

The Czech national identity seems fairly pessimistic to Americans and is often based on feelings of hopelessness and a lack of control. Although the idea of a Czech nation was not formed until the nineteenth century, and the independent Czechoslovak state was only established in 1918, the Czechs believe that their identity "...has existed since the 'dawn of history'. Czech history is considered to be discontinuous because for centuries it has been 'interrupted' by various forms of foreign oppression, by various forms of 'foreign' decisions concerning the Czech future" (Brodsky 2001 p. 23).

The oppression and foreign decisions to which Brodsky refers includes many events mentioned in the historical section of this paper including: the rule of the Habsburgs, Austria, the Austro-Hungarian Empire, the German occupation, and the occupation of the Red Army after World War II. These events helped shape the mindset of the Czech people which is sometimes labeled as defeatist. Czechs often felt as if the future did not belong to them because of foreign influence and lack of sovereignty the country has experienced. The Czechs are pessimistic and often describe the future in negative terms (Brodsky 2001).

Czechs describe the years of 1620, 1938, 1948, and 1968 as periods of darkness. During these years, the Czech people lost their ability to make decisions for themselves. Basically the Czech national identity was intentionally suppressed by outsiders. Often the Czech identity is described by a lack of self-confidence and feelings of abandonment. According to Brodsky (2001) Czechs often feel hopeless and do not feel the need to finish things they have started. Their history of occupation and influence by others has had an impact on the Czech's thought processes and identity.

Brodsky (2001) believes Czechs have a tendency to be both negative and envious of others at the same time. Brodsky (2001) mentions an old Czech joke where a man actually hopes that a neighbor's goat would die because he is jealous of the neighbor and has such a negative attitude he does not even wish a goat for himself. He simply wishes for bad things to happen to his neighbor. Another example of the Czech national identity being negative relates to the fact that the Czechs place more honor on martyrdom than they do heroics. This can be seen in the country's adulation of individuals such as Saint Wenceslaus who died a death at the hands of supposed friends at his brother's encouragement. The Czech people are proud of the strength they have shown in times of suffering; 
Czechs believe it is a great accomplishment that they have endured despite being subjected to being at the mercy of many outside occupiers and usurpers.

The idea of "littleness" is often considered to be one of the most important features of the national identity of the Czech Republic. Since the Czech Republic's history has been continuously interrupted by occupations and outside influences, Czechs do not believe that they were able to fully mature as a nation. In the past, the Czech Republic has often let politicians make important decisions for the country, and many Czech citizens simply went along with the decisions and did not actively participate in their country's government. In fact some, including Czech Prime Minister Klaus, consider Czechs to be somewhat cowardly and careless. The Czech cartoon character Soldier Schweik, created by Jaroslav Hasek, seems to personify this particular part of the Czech national identity.

While the Czechs consider themselves to be at the mercy of others and do not seem very motivated to take action that result in changes, there is another aspect to the Czech identity. The Czechs have long considered themselves to have ties to the West. Czechs believe that they are actually at the crossroads of East and West, and so they feel connected to both groups. They also consider themselves to be Central European as opposed to Eastern European, and they take the distinction seriously (Brodsky 2001).

\section{EUROPEAN IDENTITY}

When describing European identity Brodsky states, "European identity exists in terms of feeling of belonging to Europe as a continent; in terms of geographical, historical, social and cultural identification with a Europe that 'has been the cradle of civilization from the beginning of recorded history-from ancient Greeks right down to the present day"' (Wintel 1996 p. 13 quoted in Brodsky) (Brodsky 2001 p. 22). People can feel both connected to their country as well as connected to a continent such as Europe because while there are differences in history, geography, culture and social values among the different countries there are also many similarities. Residents of Europe have common bonds that link them together.

Brodsky (2001) acknowledges the fact that while people have national identities, these identities often coexist with other identities. He goes on to give examples of other groups that people often identify with. For example, he says people may identify themselves by belonging to their family, or they may have an identity based on the city or the region they are from.

\section{CZECH IDENTITY VERSUS EUROPEAN IDENTITY}

Largely absent since 1918, a great deal of optimism was felt by the Czech people after the fall of Communism in 1989. Many Czechs wanted to return to the democracy they had experienced under the first Czechoslovakian Republic.

During the Post-Communism era the Czech identity evolved. The Czechoslovak identity after Communism was that of a nation of well-educated individuals who valued democracy. The Czechoslovaks were considered to be cultured and civilized. The Czech identity was therefore closer to that of the European identity. In fact, many Czechoslovakians believed they were finally returning to Europe after an extended absence. At this point the Czechoslovakian people emphasized their identity as Central Europeans as opposed to Eastern Europeans. This is significant because it displays the country's desire to move towards Western Europe and the European Union. This part of the Czech identity emphasizes the fact that Czechoslovakians accept both a national and European identity.

The Czechs emphasize their relationship with their homeland as being important to their national identity. At the time of Brodsky's (2001), the Czechs did not consider Europe to be their homeland. This is an area that the two identities national and continental differ from each other, and the Czech national identity is given precedence over the European identity.

The Czechs have often felt powerless in regards to choices that have been made for their country, and this feeling of powerlessness is displayed in the national identity of the Czech Republic. Interestingly, Czechs regard themselves as somewhat powerless in their relationship with the European Union. "Czechs tend to feel that their 
identity within the European Union has been somehow prearranged for them, prepared by somebody else" (Brodsky 2001 p. 33). Czechs seem to believe that part of their national identity could be taken away in favor of a European identity.

One aspect of Czech identity is the tendency of Czechs to be conservative. Czechs often do not like change; Czechs are hesitant to get involved in many organizations and groups for example. Much of the Czech identity has remained the same since the time of Communism. This conservatism may be harming the country in its transition to the European Union.

The Czech national identity is often influenced by politicians in the country. The politicians have a fair amount of work to do in order to encourage individuals to relate to a national identity as well as a European identity. That being said the Czechs' emphasis on always being European is a positive sign. Also, the fact that the Czech Republic can look to the first Czechoslovakian state as an example of democracy in the nation's past helps Czechs identify with Europe and Europe's principles. Drulak (2001) believes that the Czech people are used to someone being in control because of the many years they did not have an independent state. This aspect of the Czech identity may have helped in the transition to the Czech Republic's membership in the EU. The Czechs are used to a topdown structure and should not have many issues with EU rules and regulations overriding their own laws. Finally, the Czech Republic's recent history of the reforms of the 1960s also makes the country's transition to not only having a national identity but also a European identity an easier one. Both the democratic and peaceful features of the Czech national identity helped ease the country's transition to membership in the European Union. The Czech Republic's joining of the European Union is often considered one of the more successful of all post-Communist states. Indeed, according to the Eurobarometer (2007) the number of Czechs who listed unemployment as their primary concern fell from a high of 54\% in 2004 to $21 \%$ in 2007.

Many parts of the Czech national identity are compatible with European identity. It would be interesting to monitor the evolution of the two identities over time. The national versus European identity in the Czech Republic may have implications regarding the continued success of the Czech Republic as a member of the EU.

\section{MANAGEMENT IMPLICATIONS}

Managers operating in a global environment and who deal with individuals in the Czech Republic need to be aware that the national identity of the country as perceived by many will play a role in organizational behavior. This behavior has management implications that may make or break organizational missions. Among the recommendations are the following:

- $\quad$ Provide opportunities for employee growth

- $\quad$ Provide opportunities for employee contributions to the management decision making process

- $\quad$ Foster team decision-making processes

- $\quad$ Recognize, reward and publicize employee efforts that advance the organizational mission beyond the norm and involve risk taking

Opportunities for employee growth are needed. While unemployment concerns have decreased significantly in recent years there is a need for employees to feel they can grow and develop further. Especially with the opening of borders and easy movement of goods and services among EU states Czechs need to feel as if they have some say in their future, not that they are just bound to the whims of others.

Since the national identity persona is one where people feel they are subject to the whims of outsiders, managers need to recognize that they can advance their organizational mission by providing opportunities for employees to contribute to management decision making. Seeking employee advice and counsel, long a mainstay in western and Japanese organizational philosophy, takes on new meaning and carries with it new opportunities for a typical employee. Having employees in the decision making process will assure buy-in and hopefully lead to a more effective, employee friendly environment. 
Similarly, since such involvement of employees may prove a novel idea, having team processes in place that foster and encourage team participation in management and organizational efforts may encourage individuals to get involved and advance organizational missions. Team building exercises should be introduced to the workplace so as to advance the notion that the employees have a say in the direction and tactics the organization will adopt. Such an effort will encourage buy-in by employees, which will hopefully lead to efficiencies and competitive advantages. In short, employees who participate in team efforts and decision making have ownership in the outcome.

Finally, since such employee involvement will prove a new experience to many employees, and perhaps intimidating to some, recognizing and rewarding such behavior will encourage others to become involved. Indeed, those who take risks and advance the organizational mission through their efforts need to be recognized and rewarded. By advancing team decision making, individual decision making will be fostered. Publicizing successes will serve to encourage others and work to advance the organization.

\section{CONCLUSION}

The topic of identity is a complicated and important issue. In reviewing the literature on the topic it seems as though Czech and European identities have a number of similar characteristics and also some differences. The formation of a European identity is vital to the EU, and the comparison of the Czech identity and the European identity is an important one since it could have implications for the continued success of the Czech Republic as a Member State in the Union. American managers operating in the Czech Republic need to be aware of the history of the people and its impact on their perception of identity.

\section{REFERENCES}

1. Brodsky, Jiri. "The Czech Experience of Identity." National and European Identities in EU Enlargement. (2001): 21-38.

2. $\quad$ De Beus, Jos. "Quasi-National European Identity and European Democracy." Law and Philosophy. Vol.20 (2001): 283-311.

3. Drulak, Petr. "Introduction: the Return of Identity to European Politics." National and European Identities in EU Enlargement. (2001): 11-20.

4. Eurobarometer (2007) http://ec.europa.eu/public opinion/archives/eb/eb67/eb67 cz exec.pdf Holy, Ladislav. "Metaphors of the Natural and the Artificial in Czech Political Discourse." Man. Vol. 29 (1994): 809-829.

5. Johnson, Lonnie R. Central Europe Enemies, Neighbors, Friends. Oxford University Press (2002): 1-351.

6. My Czech Republic (2007): http://www.myczechrepublic.com/czech-history

7. Random House Unabridged Dictionary (2006): http://dictionary.reference.com/browse/identity 2006 